\title{
The effects of maritime container transport on economic growth in the countries on the west coast of Latin America
}

\author{
María Jesús Freire-Seoane, Beatriz López-Bermúdez \\ and Ignacio de la Peña Zarzuelo
}

\begin{abstract}
This paper analyses the effects of changes in maritime container transport, unemployment levels, competitiveness and trade agreements on the per capita gross domestic product (GDP) of the countries on the west coast of Latin America. A sample of 23 ports along the west coast is used, with 8 observations over the period from 2008 to 2015. Panel data estimations are performed for basic fixed effects, (robust) fixed effects and panel-corrected standard error (PCSE) models, with the characteristics of the sample. In this research, the estimation method that is found to produce the best results is the PCSE model. The results support the use of containerized cargo volume as a significant variable of economic growth; they also highlight the need to invest in port infrastructure and to continue to implement outward-looking trade policy instruments.
\end{abstract}

\section{Keywords}

Maritime transport, container transport, competitiveness, unemployment, economic agreements, econometric models, transport policy, economic growth, Latin America

JEL classification

C33, F63, N76

\section{Authors}

María Jesús Freire-Seoane is a professor emeritus in the Faculty of Economics and Business of the University of La Coruña (Spain). Email: maje@udc.es.

Beatriz López-Bermúdez is a lecturer in the Faculty of Economics and Business of the University of La Coruña (Spain). Email: beatriz.lopez2@udc.es.

Ignacio de la Peña Zarzuelo is an Associate Professor in the Department of Civil Engineering of the Polytechnic University of Madrid (Spain). Email: i.delapena@upm.es. 


\section{Introduction}

Globalization has brought countries together and increased trade to such an extent that any remaining barriers are the result of different economic policy approaches, which in some cases have been very restrictive. Globalization has also meant that economies that adopt efficient logistics models can grow faster, be more competitive and increase investment. This hypothesis leads to the conjecture that logistics performance is a key factor in international trade.

It is clear that maritime transport logistics is in every respect a cross-cutting issue, encompassing not only production, trade, business development, the transport industry, information and communications technologies, control of goods, and transport and trade facilities, but also the various entities involved in the whole process. Governments thus have no shortage of reasons to get involved to developing more efficient logistics systems: to increase the competitiveness of exports and national infrastructure, to foster international trade, to open up new markets, and to boost employment in the service sector and ancillary enterprises. Governments also wish to mitigate the environmental and social externalities that are generated by congestion, accidents, insecurity and pollution from port activity (Cipoletta Tomassian, Pérez and Sánchez, 2010).

Historically, Latin American countries' trade relations have been highly dependent on developed economies, especially the United States, the European Union and, more recently, on the Asia-Pacific region. In recent years, Asian countries have become major trading partners for Latin America. To maintain these trade links, the economies on the west coast of Latin America have had to develop commercial instruments that facilitate terms of trade, and which are also fundamental to the region's development (Bernal-Meza, 2015; Girón, 2015).

Trade has been one of the drivers of the growth in Latin America and the Caribbean in recent years. In the countries on the west coast of Latin America in particular, increasing international demand for commodities, especially from the Asia-Pacific region, led to sharp rises in prices between 2009 and 2011. This resulted in widespread growth in gross domestic product (GDP) and labour productivity, as well as giving rise to an incipient and sustained policy of regional integration (ECLAC, 2014).

The main aim of this paper is to determine the effects of changes in maritime container transport, unemployment levels, competitiveness and trade agreements on the per capita GDP of the countries on the west coast of Latin America in the period from 2008 to 2015.

The article has five sections, including this introduction. Section II reviews the background provided by studies on economic growth and maritime transport. Section III outlines the research methodology, indicating the variables used in the analysis and describing the econometric model applied in the empirical analysis. The results of the estimation are presented in section IV and, lastly, the conclusions set out in section $\mathrm{V}$.

\section{Background}

The general theory on the relationship between economic growth and trade forms the basis of growth theory (Rivera-Batiz and Romer, 1991; Romer, 1990), although globalization has led to some theoretical reformulations (Bolaky and Freund, 2004; Grossman and Helpman, 1993). These approaches were first developed in the work of Radelet and Sachs (1998) and Redding (2002), and became a key element of the annual Review of Maritime Transport published by the United Nations Conference on Trade and Development (UNCTAD, n/da) from 2007 onward. However, the first research papers based on empirical specifications are relatively recent, especially regarding the relationship between port activity and economic growth (Grossmann and others, 2007). 
Research by Corbett and Winebrake (2008) shows that containerized port traffic is correlated with growth. Today, the study of the dynamics between GDP and port activity indicators is crucial to the commercial strategies of the economic actors involved in the maritime business (The Maritime Executive, 2014; Rodrigue and others, 2010) and also to research into maritime economics, which focuses on calculating additional factors to develop and strengthen the link between GDP and port activity. Other more recent studies that measure the impact of maritime traffic on countries' growth and development include Bernhofen, El-Sahli and Kneller (2016) and Rodrigue, Comtois and Slack (2013). Some authors focus on the relationship between transport costs and distances (Radelet and Sachs, 1998), while others concentrate on transport costs and cross-border cooperation agreements (Micco and Pérez, 2001). The degree of industrial specialization has also been examined (Redding, 2002).

In 2004, the Economic Commission for Latin America and the Caribbean (ECLAC) made a first attempt to highlight the economic importance of Latin American and Caribbean port infrastructure in the complex and changing global system of maritime routes. The purpose of the study was to analyse supply and demand for maritime services, freight prices, fleet ownership and port governance systems (Sánchez, 2004). In their research, UNCTAD (n/db) and Fay and Morrison (2007) also highlight the key role that Latin America could play in international maritime traffic patterns. These studies explicitly urge authorities to take advantage of the economic momentum created by high commodity prices, as many authors consider that it has not been capitalized on to reduce inequality and improve the quality and efficiency of infrastructure (Bitar, 2016).

Sánchez and others (2015) analyse the challenges and opportunities that maritime transport and port development present for Latin America and the Caribbean, introducing the issue of sustainability as a cross-cutting theme in infrastructure improvements. They affirm that, in addition to infrastructure improvements, it is essential to recognize the importance of other factors, such as the characteristics of the port terminal or the governance system, which many authors have researched in relation to the concept of efficiency (Serebrisky and others, 2016; Chang and Tovar, 2014; Núñez-Sánchez and Coto-Millán, 2012; Ramos-Real and Tovar, 2010; Coto-Millán, Baños-Pino and Rodríguez-Álvarez, 2000; and Roll and Hayuth, 1993).

The paper by López-Bermúdez, Freire and Pais (2018) shows that container terminal expansion projects have an effect on per capita GDP, in constant 2011 dollars at purchasing power parity, of 16.22\% in Pacific Alliance countries and of $11.42 \%$ in Southern Common Market (MERCOSUR) countries.

\section{Methodology}

\section{Variables}

The variables considered in the analysis are: per capita GDP, volume of goods moved expressed in twenty-foot equivalent units (TEU), unemployment rate, competitiveness index and trade agreements. Table 1 lists the variables used in the analysis.

Table 1

Variables used in the model

\begin{tabular}{llll}
\hline Type of variable & & Variable & Unit of measurement \\
\hline Dependent & $Y$ & Per capita GDP & 2011 dollars, at purchasing power parity \\
\hline Independent & $X_{1}$ & Volume of containers & Twenty-foot equivalent units (TEU) \\
\cline { 2 - 4 } & $X_{2}$ & Unemployment rate & Percentage \\
\cline { 2 - 4 } & $X_{3}$ & Competitiveness index & Index \\
\cline { 2 - 4 } & $X_{4}$ & Trade agreements & Dummy variable \\
\hline
\end{tabular}

Source: Prepared by the authors. 


\section{(a) Per capita GDP}

GDP reflects a country's production of goods and services over a given period of time, usually one year. It is the economic variable par excellence that is used as a gauge of a country's domestic prosperity or recession and is usually used as an indicator of national levels of wealth, especially in international analysis, when expressed in base year dollars and at purchasing power parity.

Per capita GDP has been calculated as the ratio of GDP to the total population of the country in each of the years analysed. In order to be able to compare different economies, a standardized value is needed, eliminating, among other factors, the effects of foreign currencies and inflation. Per capita GDP at purchasing power parity (PPP) in constant 2011 dollars is therefore used (World Bank, n/d).

Table 2 shows the per capita GDP values at PPP in constant 2011 dollars for the 2008-2015 period, for the 10 countries where the 23 ports under analysis are located. Values range from a high of US\$22,537 in Chile in 2015 to a low of $\$ 3,907$ in Nicaragua in 2009. Average per capita GDP growth for all the countries for the entire analysed period was $18.27 \%$, meaning that the annual average was $2.28 \%$.

Table 2

Latin America (10 countries): per capita GDP, 2008-2015

(Constant 2011 dollars, at purchasing power parity)

\begin{tabular}{lrrrrrrrr}
\hline & 2008 & 2009 & 2010 & 2011 & 2012 & 2013 & 2014 & 2015 \\
\hline Chile & 19032 & 18547 & 19442 & 20438 & 21330 & 21998 & 22226 & 22537 \\
\hline Colombia & 10547 & 10600 & 10901 & 11496 & 11840 & 12296 & 12716 & 12985 \\
\hline Costa Rica & 12835 & 12544 & 13000 & 13397 & 13878 & 14035 & 14392 & 14914 \\
\hline Ecuador & 9286 & 9184 & 9352 & 9927 & 10322 & 10665 & 10923 & 10777 \\
\hline El Salvador & 7501 & 7234 & 7300 & 7428 & 7533 & 7636 & 7707 & 7845 \\
\hline Guatemala & 6782 & 6670 & 6714 & 6844 & 6899 & 7005 & 7147 & 7293 \\
\hline Mexico & 16008 & 15012 & 15535 & 15923 & 16324 & 16316 & 16459 & 16668 \\
\hline Nicaragua & 4092 & 3907 & 4029 & 4231 & 4453 & 4619 & 4785 & 4961 \\
\hline Panama & 14867 & 14839 & 15419 & 16940 & 18184 & 19057 & 19872 & 20674 \\
\hline Peru & 9323 & 9309 & 9957 & 10449 & 10944 & 11430 & 11545 & 11768 \\
\hline
\end{tabular}

Source: Prepared by the authors, on the basis of data from World Bank, "Indicators", n/d [online] https://data.worldbank.org/ indicator?tab=all.

\section{(b) Volume of containers}

The effect of maritime transport on a country's economy can be measured using different indicators. This study uses containerized goods because they have the highest added value in the goods and services market, and thus theoretically generate significant benefits that improve the standard of living.

Multimodal transport and container shipping are two factors that have developed simultaneously over the same period of time. Analysis of containerized goods therefore faithfully reflects the development of infrastructure for the consumer logistics chain. The use of container shipping, combined with economies of scale, has led to mega container vessels being built, that now have a capacity of 24,000 TEU. In addition, the driver of intermodal transport has undoubtedly been the container, which permits easy handling between modal systems (Rodrigue, Comtois and Slack, 2013).

The volume of goods handled in the period 2008-2015 in each of the analysed ports on the west coast of Latin America is expressed in TEU (ECLAC, $n / d)$. 
TEU moved at these ports are included in the econometric model as an indicator, since when producing the estimates, the variables must be expressed in the same units. For this reason, absolute values have not been used (Guisan, 2008). The TEU variable is expressed in thousands and values range from 8,151 in the port of Balboa (Panama) to a minimum of 0 in the port of Coronel (Chile).

Figure 1 shows the trend in containerized cargo movements in the 2008-2015 period. An index has been calculated taking 2008 as the base year with a value of 100 . According to available information, container movements fell by 12 percentage points to 88 in 2009. However, from 2010 onward container movements in the countries of the west coast of Latin America followed a path of growth; despite some fluctuations, variation rates remained positive. In 2010, the TEU movement indicator reached 106.27, with a growth rate of $20.46 \%$. This two-digit growth was maintained in 2011 , with $17.92 \%$, and the absolute value continued to rise in 2012, hitting 134, although the growth rate slowed to $7.2 \%$. Growth decelerated further in 2013, falling to 2.23\%; however, the absolute values climbed to 147 in 2014 and 2015 -the most recent years analysed - with growth rates of $7.30 \%$ and $6.12 \%$, respectively.

Figure 1

Latin America (10 countries): TEU indicator, 2008-2015ª

(Base year $2008=100$ )

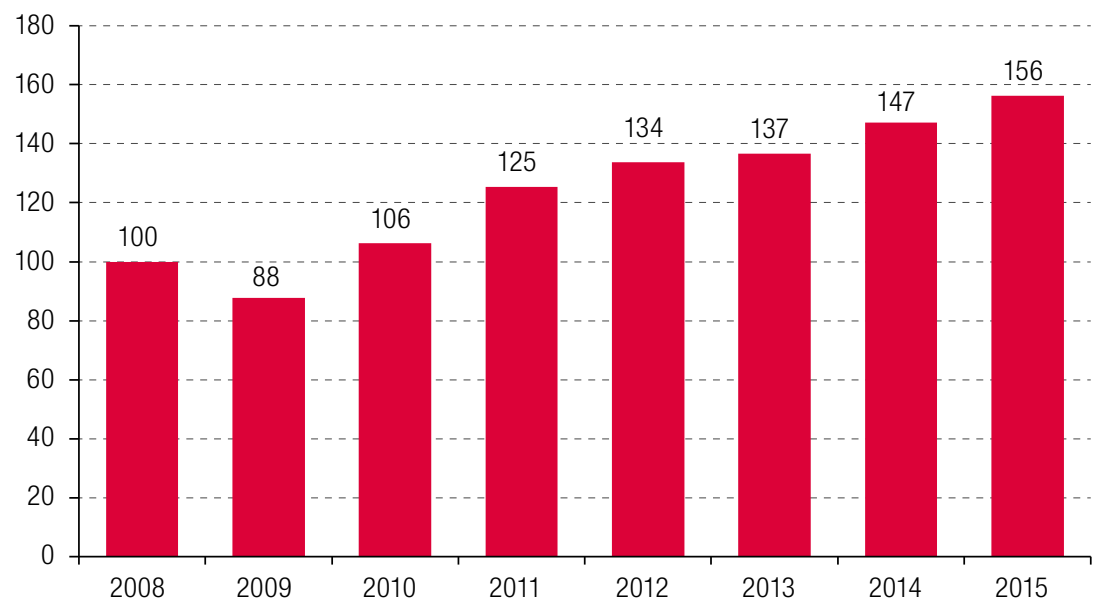

Source: Prepared by the authors, on the basis of data from Economic Commission for Latin America and the Caribbean (ECLAC), Maritime and Logistics Profile of Latin America and the Caribbean, n/d [online] http://perfil.cepal.org///en/start.html.

a The countries included are: Chile, Colombia, Costa Rica, Ecuador, El Salvador, Guatemala, Mexico, Nicaragua, Panama and Peru.

\section{(c) Unemployment rate}

The unemployment rate is expressed as the percentage of the economically active population in each of the countries studied that is seeking employment and has not found it, for each of the years analysed (World Bank, n/d). The unemployment rate reflects the labour market situation.

Table 3 shows the unemployment rate of these countries for the 2008-2015 period. If the last year of the series is not included, the maximum value is $12.07 \%$ in 2009 in Colombia and the minimum value is $2.79 \%$ in 2008 in Guatemala. In 2015, the highest unemployment rate was in Costa Rica (9.61\%), while Guatemala continued to have the lowest rate $(2.42 \%)$. 
Table 3

Latin America (10 countries): unemployment rate, 2008-2015

(Percentages)

\begin{tabular}{lrrrrrrrr}
\hline & 2008 & 2009 & 2010 & 2011 & 2012 & 2013 & 2014 & 2015 \\
\hline Chile & 7.80 & 9.69 & 8.14 & 7.12 & 6.43 & 5.93 & 6.39 & 6.21 \\
\hline Colombia & 11.27 & 12.07 & 11.83 & 10.88 & 10.43 & 9.70 & 9.15 & 8.95 \\
\hline Costa Rica & 4.78 & 7.71 & 8.92 & 10.31 & 10.17 & 9.38 & 9.62 & 9.61 \\
\hline Ecuador & 7.30 & 6.47 & 5.02 & 4.21 & 4.12 & 4.15 & 3.80 & 4.77 \\
\hline El Salvador & 5.88 & 7.33 & 7.05 & 6.62 & 6.07 & 5.93 & 5.92 & 6.18 \\
\hline Guatemala & 2.79 & 3.08 & 3.74 & 4.13 & 2.87 & 2.99 & 2.91 & 2.42 \\
\hline Mexico & 3.90 & 5.38 & 5.33 & 5.19 & 4.92 & 4.94 & 4.83 & 4.34 \\
\hline Nicaragua & 6.20 & 8.20 & 8.00 & 7.42 & 6.74 & 5.30 & 5.27 & 5.61 \\
\hline Panama & 5.60 & 6.60 & 6.50 & 4.48 & 4.05 & 4.10 & 4.82 & 5.35 \\
\hline Peru & 6.64 & 4.40 & 4.00 & 3.90 & 3.60 & 4.00 & 4.08 & 4.42 \\
\hline
\end{tabular}

Source: Prepared by the authors, on the basis of data from World Bank, "Indicators", n/d [online] https://data.worldbank.org/ indicator?tab=all.

\section{(d) Competitiveness index}

The Global Competitiveness Index (GCl) is produced and published by the World Economic Forum (Schwab, 2016) and seeks to rank the competitiveness of each country according to a common global scale. The range for this indicator is $1-7$, where 1 is the lowest possible value and 7 the highest. To obtain this indicator, different aspects of the country are analysed, grouped under 12 pillars:

- Pillar 1: Institutions

- Pillar 2: Infrastructure

- Pillar 3: Macroeconomic environment

- Pillar 4: Health and primary education

- Pillar 5: Higher education and training

- Pillar 6: Goods market efficiency

- Pillar 7: Labour market efficiency

- Pillar 8: Financial market development

- Pillar 9: Technological readiness

- Pillar 10: Market size

- Pillar 11: Business sophistication

- Pillar 12: Innovation

Worldwide, the highest value in the Global Competitiveness Index in 2016 was that of Switzerland, with 5.81. Within the group of countries analysed, the top place is held by Chile, with 4.64, putting the it thirty-third globally, followed by Panama, with 4.51, in forty-second place.

Table 4 gives the competitiveness index values for the countries covered by this study for the 2008-2015 period. In 2008, the values ranged from 4.75 for Chile to 3.32 for Nicaragua. Over the period under review, the indicator improved in almost all the countries, with the exception of Chile, where it gradually worsened, reaching 4.60 in 2015; although Chile remains the best positioned country in relative terms. In 2015 Nicaragua still had the lowest competitiveness index score of the group; however, its situation has consistently improved, with an index value at 3.82. The scores for the remaining countries lie between these maximum (Chile) and minimum (Nicaragua) values, ranging from 4.01 for El Salvador to 4.43 for Panama. 
Table 4

Latin America (10 countries): competitiveness index, 2008-2015

(Scores on a scale from 1 to 7 )

\begin{tabular}{lllllllll}
\hline & $\mathbf{2 0 0 8}$ & $\mathbf{2 0 0 9}$ & $\mathbf{2 0 1 0}$ & $\mathbf{2 0 1 1}$ & $\mathbf{2 0 1 2}$ & $\mathbf{2 0 1 3}$ & $\mathbf{2 0 1 4}$ & 2015 \\
\hline Chile & 4.75 & 4.70 & 4.72 & 4.69 & 4.70 & 4.65 & 4.61 & 4.60 \\
\hline Colombia & 4.03 & 4.05 & 4.05 & 4.14 & 4.20 & 4.18 & 4.19 & 4.23 \\
\hline Costa Rica & 4.20 & 4.25 & 4.23 & 4.31 & 4.27 & 4.34 & 4.35 & 4.42 \\
\hline Ecuador & 3.36 & 3.56 & 3.58 & 3.65 & 3.82 & 3.94 & 4.18 & 4.22 \\
\hline El Salvador & 4.00 & 4.02 & 3.99 & 3.89 & 3.99 & 3.80 & 3.84 & 4.01 \\
\hline Guatemala & 3.92 & 3.96 & 4.04 & 3.94 & 4.00 & 4.01 & 4.04 & 4.10 \\
\hline Mexico & 4.18 & 4.19 & 4.19 & 4.29 & 4.23 & 4.34 & 4.36 & 4.27 \\
\hline Nicaragua & 3.32 & 3.44 & 3.57 & 3.41 & 3.61 & 3.73 & 3.84 & 3.82 \\
\hline Panama & 4.18 & 4.21 & 4.24 & 4.33 & 4.35 & 4.49 & 4.50 & 4.43 \\
\hline Peru & 3.93 & 4.01 & 3.95 & 4.11 & 4.21 & 4.28 & 4.25 & 4.24 \\
\hline
\end{tabular}

Source: Prepared by the authors, on the basis of data from K. Schwab (ed.), The Global Competitiveness Report 2016-2017, Geneva, 2016 [online] http://www3.weforum.org/docs/GCR2016-2017/05FullReport/TheGlobalCompetitivenessReport2016-2017_ FINAL.pdf.

\section{(e) Trade agreements}

As stated above, trade has been a determining factor in the economic growth of the group of countries under analysis. While trade was buoyant in 2009-2011, thanks to higher commodity prices (ECLAC, 2014), international trade is now sluggish, mainly owing to falling demand for commodities from China. However, growth is beginning to pick up on the back of South-South trade, fuelled by the fourth industrial revolution (big data and e-commerce) (UNCTAD, n/da).

Given that trade is extremely important to the economies analysed, it is necessary to study how they have opened up to trade, with a shared goal of liberalizing commerce and eliminating barriers, to promote trade with countries in the region and those outside it. A descriptive analysis is therefore needed of the policies on free trade agreements of the countries considered in this study.

Latin America and the Caribbean has pursued a multitude of regional agreements to expand the market for goods and services by removing barriers between neighbouring countries. However, these projects - such as the Andean Community (CAN), established in 1969 as the Andean Pact; the Amazon Cooperation Treaty Organization (ACTO), created in 1978; and the Latin American Integration Association (LAIA), set up in 1980 - have not achieved the expected results. The most important prevailing trade integration mechanisms are the Southern Common Market (MERCOSUR), set up in 1991; the Bolivarian Alliance for the Peoples of Our America - Peoples' Trade Agreement (ALBA-TCP), established in 2004; and the Pacific Alliance, created in 2011.

These agreements seek to form economic blocs that favour trade relations and support the development of the signatory countries. However, when it comes to making decisions, positions differ considerably, ranging from the openness of the Pacific Alliance to the protectionism of ALBA-TCP.

The member countries of the Pacific Alliance (Chile, Colombia, Mexico and Peru) follow a clear model of openness and liberalization. These States have ratified free trade agreements with various economies outside the region. These agreements are trade policy tools that help to develop competitive export and import exchanges, while producing economic, employment and social improvements. They often boost foreign investment by providing certainty and stability to investors.

Analysis of the free trade agreements that these countries have ratified shows that, in recent years, those with Asian countries have had the greatest impact on their economies. In conclusion, it can be said that: 
- Latin American countries have entered into a multitude of regional agreements. Many have not succeeded, and others have promoted trade among member countries (for example, MERCOSUR). In this context, the Pacific Alliance has emerged as a trading bloc that promotes exchanges among its member countries and also exports outside the region.

- Most of the free trade agreements that Latin American countries have ratified have been with countries in the same region, with European partners and with the United States. However, in the period under review, the Asian economies, specifically China and Japan, have risen the most in the ranking of these economies' key trading partners.

\section{Econometric model}

A sample of 23 ports along the west coast of Latin America is used, with 8 observations over the 2008-2015 period. The ports are: Antofagasta, Arica, Coronel, lquique, Lirquén, Mejillones, San Antonio, San Vicente and Valparaíso (Chile); Buenaventura (Colombia); Caldera (Costa Rica); Esmeraldas and Guayaquil (Ecuador); Acajutla (El Salvador); Puerto Quetzal (Guatemala); Ensenada, Lázaro Cárdenas and Manzanillo (Mexico); Corinto (Nicaragua); Balboa (Panama); Callao, Matanari and Paita (Peru). As there are more units of cross-sectional data available (23 ports) than time series (8 years), panel data estimates $(N>T)$ are used, instead of time series data $(N<T)$.

Greene (2003) states that the fundamental advantage of a panel data set over cross-sectional data is that it will allow greater flexibility in models, while taking into account the differences between the units that make up the model. Their main advantages include the fact that:

- No rigid assumptions are needed for panel data, while in the case of cross-sectional data, especially for the maximum likelihood estimation (MLE) model, distribution assumptions for each error component are needed to separate technical inefficiency from statistical noise. In addition, MLE analysis requires that technical inefficiency be independent of regressors.

- The technical efficiency for each unit can be estimated consistently with panel data. Although it is also possible to produce estimates using cross-sectional data, this is not consistent.

- Panel data provide more information about the behaviour of units over time, which cannot be analysed with cross-sectional data - such as changes in structure and factors that vary or do not vary over time- through fixed and random effects analysis.

The model specification is based on the basic structure proposed by Greene (2003):

$$
Y_{i t}=x_{i t}^{\prime} \beta+z_{i}^{\prime} \alpha+\varepsilon_{i t}
$$

Where:

$Y_{i t}$ is the variable to be explained;

$x^{\prime}{ }_{i t}$ is a vector of explanatory variables $(K \times 1)$;

$z_{i}^{\prime} \alpha$ are the individual effects, where $z_{i}$ contains a constant term and a set of individual or group variables, which may be observable or not;

$\beta$ is the slope vector of the equation;

$t$ is the time series up to period $T(t=1,2, \ldots, T)$;

$i$ refers to individuals, the last one being individual $N(i=1,2, \ldots, N)$;

$\varepsilon_{i t}$ is the error term.

Based on the structure of the proposed econometric model, the following specification is presented: 


$$
\operatorname{LpcGDP}_{i t}=\beta_{0}+\beta_{1} \cdot L T E U_{i t}+\beta_{2} \cdot L U n e m p_{i t}+\beta_{3} \cdot L G C I_{i t}+\beta_{4} \cdot T_{i t}+\varepsilon_{i t}
$$

Where:

$\operatorname{LpcGDP}$ it is the natural logarithm of per capita GDP at purchasing power parity expressed in constant 2011 dollars of the country where port $i$ is located in year $t$ (World Bank, $\mathrm{n} / \mathrm{d}$ );

$L T E U_{i t}$ is the natural logarithm of TEUs handled at port $i$ in year $t(E C L A C, \mathrm{n} / \mathrm{d})$;

LUnemp $_{i t}$ is the natural logarithm of the unemployment rate of the country where port $i$ is located in year $t$ (World Bank, $\mathrm{n} / \mathrm{d}$ );

$L G C I_{i t}$ is the natural logarithm of the competitiveness index of the country where port $i$ is located in year $t$ (Schwab, 2016);

$T_{i t}$ is the dummy variable with a value of 1 for a country that signs an outward-looking trade agreement (Pacific Alliance) or that ratifies a free trade agreement with an Asian country in a given year, or with a value of 0 otherwise, at port $i$ in year $t$;

$\beta_{m}$ represents each of the coefficients of explanatory variables $m$;

$t$ is the 2008-2015 period;

$i$ is each of the analysed ports;

$\varepsilon_{i t}$ is the error term.

The fixed effects model is the most widely used model in economics and political science (Schurer and Yong, 2012). In addition, according to Wooldridge (2010), the fixed effects transformation is useful for policy analysis and economic programme evaluation. Brüderl and Ludwig (2015) argue that standard regression models provide biased estimates if there are unobserved intrinsic characteristics, while fixed effects regression is a method that can provide unbiased estimates under the same circumstances.

Before producing estimates by means of a fixed effects model (Brüderl and Ludwig, 2015; Gangl, 2010; Allison, 2009), random effects model or panel-corrected standard errors (PCSE) model (Rodríguez, 2017; Marques and Fuinhas, 2012; Reed and Webb, 2010), statistical tests must be performed to determine the characteristics of the data in the sample and to correctly select both the appropriate specification and econometric method.

The tests verify whether there is heteroscedasticity, temporal autocorrelation or contemporaneous correlation between cross-sectional units. Furthermore, if the presence of heteroscedasticity is detected (modified Wald test for groupwise heteroscedasticity), this means that the initial fixed effects estimate is not accurate and, therefore, a fixed effects estimate is calculated with a heteroscedasticity-robust error estimator of variance.

Lastly, the presence of autocorrelation and contemporaneous correlation ultimately leads to the use of the PCSE method specified by Beck and Katz (1995). This method is used to calculate the standard errors and the estimates of variance-covariance; errors are assumed to be heteroscedastic by default with contemporaneous correlation between panels (entities).

The variables in the model are expressed in logarithms, with the exception of the variable for treaties, which is included as a dummy variable.

\section{(a) The Hausman test}

The statistical test proposed by Hausman (1978) is based on a chi-square test to determine whether there are systematic and significant differences between two given estimates. The Hausman test has been widely used to determine the appropriateness of using a fixed effects or a random effects 
estimator in the context of specifications for panel data (Wooldridge, 2010; Greene, 2001). Fixed effects model specifications are, in principle, more appropriate when using a set of observations divided into cross-sectional units, as is the case with panel data. However, according to Baltagi (2008), if the number of cross-sectional units is too high in relation to the number of temporal units, a fixed effects model estimation will cause a significant loss of degrees of freedom, which will generally entail a higher variance of the estimated parameters; in such cases, it is proposed that the random effects estimator be used.

Table 5 presents the results of the Hausman test to determine whether a random effects model should be used.

Table 5

Results of the Hausman test

\begin{tabular}{|c|c|c|c|c|}
\hline & Fixed coefficients (b) & Random coefficients (B) & Difference (b-B) & Standard error \\
\hline LTEU & 0.0298407 & 0.0303932 & -0.0005525 & 0.0029095 \\
\hline LUnemp & -0.2317544 & -0.1801522 & -0.0516022 & 0.0077272 \\
\hline LGCl & 0.521414 & 0.8465897 & -0.3251758 & 0.0417249 \\
\hline Treaties & 0.0640417 & 0.1101613 & -0.0461196 & 0.0072828 \\
\hline \multicolumn{5}{|c|}{ Test: $\mathrm{H}_{0}$ : Non-systematic difference in coefficients } \\
\hline \multicolumn{5}{|c|}{$\chi^{2}(7)=(b-B)^{\prime}\left[\left(V \_b-V \_B\right) \wedge(-1)\right](b-B)=64.28$} \\
\hline \multicolumn{5}{|c|}{ Prob $>\chi^{2}=0.0000$} \\
\hline
\end{tabular}

Source: Prepared by the authors.

Note: Calculations performed in Stata 13. LTEU: natural logarithm of TEUs (twenty-foot equivalent units) handled; LUnemp: natural logarithm of the unemployment rate; LGCl: natural logarithm of the competitiveness index.

The results obtained allow us to reject the null hypothesis $(p<0.05)$ of equality with a $95 \%$ confidence level and, therefore, we must assume that the fixed effects estimation is appropriate.

\section{(b) Wooldridge test for autocorrelation in panel data}

Autocorrelation in a time series of a process $X_{t}$ is the correlation of that process with a time-shifted version of the time series itself. According to Drukker (2003), autocorrelation in panel data models biases the standard errors and causes the results to be less efficient. Autocorrelation must therefore be identified in the idiosyncratic error term in the model. Baltagi and Wu (1999) set out a test similar to that of Wooldridge (2003), which was shown to have optimal power with a series of assumptions concerning the individual effects of the model being tested. However, according to Drukker (2003), the Wooldridge test should be less powerful than more highly parametrized tests because it requires relatively few assumptions and is easy to implement, but it should be more robust.

Under the null hypothesis of no serial correlation, the regression residuals of the first differences should have an autocorrelation of -0.5. This means that the coefficient of a regression based on the lagged residuals over current residuals should be -0.5. The results of this test are shown in Table 6 .

Table 6

Wooldridge test results

\begin{tabular}{c}
\hline $\mathrm{H}_{0}$ : No first-order autocorrelation \\
\hline $\mathrm{F}(1.22)=133.025$ \\
$\mathrm{Prob}>\mathrm{F}=0.0000$ \\
\hline
\end{tabular}

Source: Prepared by the authors.

Note: Calculations performed in Stata 13 
The null hypothesis of no first-order correlation is rejected, and it is assumed that first-order autocorrelation exists in the model.

\section{(c) Testing for groupwise homoscedasticity}

In order to use a statistical inference based on the ordinary least squares (OLS) covariance matrix, it must be assumed that, in addition to no autocorrelation, that there is homoscedasticity in the data. The difference in variance of each of the model's entities (or panels) must be tested to accept or reject the hypothesis of homoscedasticity.

In Table 7, a modified Wald test is run to test for groupwise heteroscedasticity in the residuals of the specific fixed effects regression model, as proposed by Greene (2003). The null hypothesis $\sigma_{i}{ }_{i}=\sigma^{2}$ is proved for $i=1,2, \ldots, N_{g}$, where $N_{g}$ is the number of cross-sectional units. The result of this modified Wald test will be distributed as an $\chi^{2}\left[N_{g}\right]$, under the null hypothesis of homoscedasticity. According to Baum (2001), the power of this test is low for small samples when $N>T$, so the results obtained should be taken with caution.

Table 7

Modified Wald test for groupwise heteroscedasticity

\begin{tabular}{c}
\hline$H_{0}: \sigma^{2}{ }_{i}=\sigma^{2}$, for all $i=1,2,3, \ldots, 34$ \\
$\chi^{2}(23)=1374.93$ \\
Prob $>\chi^{2}=0.0000$
\end{tabular}

Source: Prepared by the authors.

Note: Calculations performed in Stata 13.

The null hypothesis of groupwise heteroscedasticity in the regression residuals is rejected.

\section{(d) Pesaran's cross-section dependence test}

According to De Hoyos and Sarafidis (2006), panel data models are likely to exhibit substantial cross-sectional dependence (or contemporaneous correlation) which may arise because of the presence of common shocks and unobserved components that ultimately become part of the error term. The same has been argued in the studies by Robertson and Symons (2000), Anselin (2001), Pesaran (2004) and Baltagi (2008).

Pesaran's test (see table 8) tests the hypothesis of cross-sectional independence in panel data models with $\mathrm{N}>\mathrm{T}$, by implementing the parametric testing procedure proposed by Pesaran (2004). It is for this reason that the Breusch-Pagan test was ruled out as a possible means of detecting contemporaneous correlation in the model residuals, in favour of the Pesaran's alternative approach.

Table 8

Pesaran test

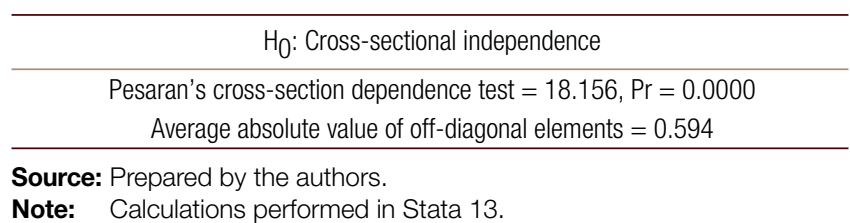

Note: Calculations performed in Stata 13.

The null hypothesis of cross-sectional independence is rejected and, therefore, the existence of cross-sectional dependence (contemporaneous correlation) is assumed. 


\section{Results}

The tests performed detected that the sample presents the following characteristics: heteroscedasticity, autocorrelation and contemporaneous correlation. In addition, the Hausman test indicates that between a fixed effects and a random effects estimation, the fixed effects estimation is preferable (Wooldridge, 2010; Greene, 2001).

In the research carried out by Rodríguez (2017), a sample of data with the same characteristics is presented and certain estimates are made; he finds that PCSE estimation is the most appropriate in these circumstances. Lastly, in this research the estimation method that offers the best results is the PCSE model, applying the Prais-Winsten transformation (Prais and Winsten, 1954) beforehand, to correct first-order autocorrelation. It is also possible to calculate an autoregressive coefficient for each panel (known in the literature as panel-specific $A R(1)$ ) or to calculate a common autoregressive coefficient across all panels. It could be assumed a priori - since the sample is of a heterogeneous group of countries, although all are developing countries, with the exception of Chile and Mexico - that there is a different autoregression coefficient for each port. However, based on Beck and Katz (1995), it is suggested, as in the cross-sectional and panel time series models where the parameters of interest $\beta$ do not vary for each cross-sectional unit, that the autocorrelation parameter should not vary either.

Since the sample's panel data are balanced, the strategy that has been followed to calculate the covariance is based on using all the observations that are common to each pair of panels to compute each element of the covariance matrix. Calculation of autocorrelation of time series has been selected as the method for calculating the autocorrelation parameter, all other alternatives being consistent and asymptotically equivalent.

Table 9 contains the results of the three estimations: basic fixed effects, which is the fixed effects estimator without any correction; fixed effects with a heteroscedasticity-robust error estimator of variance; and the PCSE model, with sample characteristics, meaning corrected for autocorrelation, contemporaneous correlation and heteroscedasticity. The estimation is performed for all 23 ports over 8 years, making a total of 184 observations. All of the model's variables are expressed as logarithms, except the variable that refers to trade agreements, which is treated as a dummy variable.

The data obtained from the model estimations allow us to identify some significant differences. In the two fixed effects estimations, Rho assumes a value of 0.98535966, while, in the case of PCSE, its value is reduced to 0.7022694 . So, while the fixed effects estimations have the highest Rho value, when considering $R^{2}$ within (0.5868), between (0.2488) and overall $(0.2346)$, these values are much lower than the $\mathrm{R}^{2}$ of the PCSE model (0.9955).

In the fixed effect estimations, the variables analysed (LTEU, LUnemp, LGCl and trade agreements) are significant with a 95\% confidence level and the estimated coefficients do not show variations. The results show that a $1 \%$ increase in the TEU indicator represents $0.0298 \%$ growth in per capita GDP. A $1 \%$ increase in the unemployment rate translates into a reduction in per capita GDP of $0.2318 \%$. With regard to the competitiveness index, an improvement of $1 \%$ leads to an increase in per capita GDP of $0.5214 \%$. Lastly, the existence of an outward-looking trade policy results in an increase in per capita GDP of $0.0640 \%$.

Fixed effects estimates are consistent, but not efficient, given the characteristics of the sample's variables. Therefore, the PCSE estimation is carried out, with LUnemp as the only variable that does not appear as significant; this may be because - as stated in the research by Cipoletta Tomassian, Pérez and Sánchez (2010) - investments in infrastructure in the countries under analysis have been low and, therefore, have not influenced the labour market. 
Table 9

Fixed effects model and panel-corrected standard errors model (PCSE)

\begin{tabular}{|c|c|c|c|c|c|}
\hline \multicolumn{6}{|c|}{$L p c G D P_{i t}=\beta_{0}+\beta_{1} \cdot L T E U_{i t}+\beta_{2} \cdot L U n e m p_{i t}+\beta_{3} \cdot L G C I_{i t}+\beta_{4} \cdot T_{i t}+\varepsilon_{i t}$} \\
\hline & & & Fixed effects & (Robust) fixed effects & PCSE \\
\hline$\beta_{0}$ & & & 8.982853 & 8.982853 & 5.400565 \\
\hline Standard error & & & 0.2009241 & 0.4333786 & 0.6216013 \\
\hline$P>|t|$ & & & 0.000 & 0.000 & 0.000 \\
\hline \multirow[t]{3}{*}{ LTEU } & & $\beta_{1}$ & 0.0298407 & 0.0298407 & 0.0155947 \\
\hline & & Standard error & 0.0083282 & 0.0130366 & 0.0074627 \\
\hline & & $P>|t|$ & 0.000 & 0.032 & 0.037 \\
\hline \multirow[t]{3}{*}{ LUnemp } & & $\beta_{2}$ & -0.2317544 & -0.2317544 & 0.0383143 \\
\hline & & Standard error & 0.0241899 & 0.059507 & 0.0508677 \\
\hline & & $P>|t|$ & 0.000 & 0.001 & 0.451 \\
\hline \multirow[t]{3}{*}{$\mathrm{LGCl}$} & & $\beta_{3}$ & 0.521414 & 0.521414 & 2.612246 \\
\hline & & Standard error & 0.1267077 & 0.2265887 & 0.4352533 \\
\hline & & $P>|t|$ & 0.000 & 0.031 & 0.000 \\
\hline \multirow[t]{3}{*}{$T$} & & $\beta_{4}$ & 0.0640417 & 0.0640417 & 0.2836674 \\
\hline & & Standard error & 0.0231973 & 0.0117699 & 0.0508644 \\
\hline & & $P>|t|$ & 0.006 & 0.000 & 0.000 \\
\hline $\mathrm{N}$ & & & 184 & 184 & 184 \\
\hline $\mathrm{F}$ & & & 55.74 & 538.78 & \\
\hline $\mathrm{P}>\mathrm{F}$ & & & 0.000 & 0.000 & \\
\hline Wald $\mathrm{Chi}^{2}$ & & & & & 164.79 \\
\hline $\mathrm{P}>\mathrm{Chi}^{2}$ & & & & & 0.000 \\
\hline $\operatorname{COV}\left(v_{j}, x_{i, j}\right)$ & & & 0.2739 & 0.2739 & \\
\hline Rho & & & 0.98535966 & 0.98535966 & 0.7022694 \\
\hline $\mathrm{R}^{2}$ & & & & & 0.9955 \\
\hline \multirow[t]{3}{*}{$\mathrm{R}^{2}$} & Within & & 0.5868 & 0.5868 & \\
\hline & Between & & 0.2488 & 0.2488 & \\
\hline & Overall & & 0.2346 & 0.2346 & \\
\hline Estimated covariance & & & & & 276 \\
\hline Estimated autocorrelation & & & & & 1 \\
\hline Estimated coefficients & & & & & 5 \\
\hline
\end{tabular}

Source: Prepared by the authors.

Note: Calculations performed in Stata 13.

Regarding the PCSE model estimation, the LTEU, LGCl and trade agreement variables, in addition to being significant, have positive signs. In quantitative terms, a 1\% increase in the TEU indicator results in $0.0156 \%$ growth in per capita GDP. A $1 \%$ increase in the competitiveness index results in a $2.61 \%$ rise in per capita GDP. In addition, the existence of an economic policy based on outward-looking free trade agreements or treaties with Asian countries results in an increase in per capita GDP of $0.2837 \%$.

The results show that the competitiveness index has a significant impact on per capita GDP. This percentage is justified, primarily, by the configuration of the variable, since the index is prepared through analysis of different aspects of each country and the values range from 1 to 7 . Specifically, in the 10 countries analysed, the values of the variable range from 3.32 to 4.75 in the period studied (2008-2015). In short, its limited variation and the grouping of so many aspects under a single indicator means that a slight increase in the index indicates that the country has improved considerably and, therefore, the effect of this on per capita GDP is clearly evident.

Lastly, the increase in per capita GDP resulting from the existence of outward-looking trade agreements or treaties with Asian countries, means that the outward-looking trade policy implemented toward the end of the twentieth century has boosted the development of Latin American countries. In addition, these economies did not suffer as severely from the effects of the global financial crisis. 


\section{Conclusions}

Maritime transport accounts for $80 \%$ of world trade (UNCTAD, n/db). This research focuses on only one part of maritime transport: that which transports goods in containers. This is done for two important reasons: firstly, because of the trade boom in the logistics of containers with standardized measurements (TEU); and, secondly, because containerized goods is the form of freight trade with the highest added value. In short, containerized transport is a faithful reflection of the form of trade in goods with the most added value in the countries analysed. Therefore, such transport has very significant effects on these economies, by promoting considerable socio-economic development.

The results of the estimation support the hypothesis that an increase in containerized trade through ports has an impact on the growth of a country's economy and therefore that this type of trade benefits the entire population. Specifically, with regard to the estimation, the TEU indicator, competitiveness index and trade agreements variables, in addition to being significant, all have positive signs, meaning that their effects on per capita GDP are positive. In quantitative terms, a 1\% increase in the TEU indicator results in $0.0156 \%$ growth in per capita GDP, while a $1 \%$ increase in the competitiveness index brings about a $2.61 \%$ rise in per capita GDP.

The trade agreements variable is intended to measure the effect of an outward-looking trade policy. Such approaches were boosted in the analysed period by trade with Asian countries, with whom a number of countries on the west coast of Latin America have free trade agreements. The existence of such a policy results in an increase in per capita GDP of $0.2837 \%$.

The results show that the competitiveness index is the variable with the greatest impact on per capita GDP. This can be explained by how the index is obtained and by the limited variability of the sample analysed (with values between 3.32 and 4.75); consequently, a slight rise in the index translates into a considerable impact on per capita GDP.

Lastly, in the period analysed -2008 to 2015 - the economies of the countries on the west coast of Latin America have been boosted by the trade policy instruments they have developed and by high commodity prices. The effects of these two factors can be measured through the volume of containerized goods transported, which is a faithful estimator of trade. However, it can also be concluded that these countries must increase investment in port infrastructure and modernize and adapt it to today's needs, since such facilities generate long-term economic benefits for the economy, and therefore also for the population.

\section{Bibliography}

Allison, P. D. (2009), Fixed Effects Regression Models, New York, Sage.

Anselin, L. (2001), "Spatial effects in econometric practice in environmental and resource economics", American Journal of Agricultural Economics, vol. 83, No. 3, Oxford, Oxford University Press.

Baltagi, B. (2008), Econometric Analysis of Panel Data, Hoboken, Wiley.

Baltagi, B. H. and P. X. Wu (1999), "Unequally spaced panel data regressions with AR (1) disturbances", Econometric Theory, vol. 15, No. 6, New York, Cambridge University Press.

Baum, C. F. (2001), "XTTEST3: Stata module to compute Modified Wald statistic for groupwise heteroskedasticity", Statistical Software Components, No. S414801, Boston, Boston College.

Beck, N. and J. N. Katz (1995), "What to do (and not to do) with time-series cross-section data", American Political Science Review, vol. 89, No. 3, New York, Cambridge University Press.

Bernal-Meza, R. (2015), "Alianza del Pacífico versus Alba y Mercosur: entre el desafío de la convergencia y el riesgo de la fragmentación de Sudamérica”, Pesquisa e Debate, vol. 26, No. 1, São Paulo, Pontifical Catholic University of São Paulo. 
Bernhofen, D. M., Z. El-Sahli and R. Kneller (2016), "Estimating the effects of the container revolution on world trade", Journal of International Economics, vol. 98, Amsterdam, Elsevier.

Bitar, S. (2016), "Las tendencias mundiales y el futuro de América Latina", Public Administration series, No. 78 (LC/L.3681), Santiago, Economic Commission for Latin America and the Caribbean (ECLAC).

Bolaky, B. and C. L. Freund (2004), "Trade, regulations, and growth", Policy Research Working Paper, No. 3255, Washington, D.C., World Bank.

Brüderl, J. V. and V. Ludwig (2015), "Fixed-effects panel regression", The Sage Handbook of Regression Analysis and Causal Inference, H. Best and C. Wolf (eds.), Los Angeles, Sage.

Chang, V. and B. Tovar (2014), "Drivers explaining the inefficiency of Peruvian and Chilean ports terminals", Transportation Research Part E: Logistics and Transportation Review, vol. 67, Amsterdam, Elsevier.

Cipoletta Tomassian, G., G. Pérez and R. Sánchez (2010), "Políticas integradas de infraestructura, transporte y logística: experiencias internacionales y propuestas iniciales", Natural Resources and Infrastructure series, No. 150 (LC/L.3226-P), Santiago, Economic Commission for Latin America and the Caribbean (ECLAC).

Corbett, J. J. and J. Winebrake (2008), The Impacts of Globalisation on International Maritime Transport Activity: Past Trends and Future Perspectives, Paris, Organization for Economic Cooperation and Development (OECD)/International Transport Forum (ITF).

Coto-Millán, P., J. Baños-Pino and A. Rodríguez-Álvarez (2000), "Economic efficiency in Spanish ports: some empirical evidence", Maritime Policy \& Management, vol. 27, No. 2, Abingdon, Taylor \& Francis.

De Hoyos, R. E. and V. Sarafidis (2006), "Testing for cross-sectional dependence in panel-data models", The Stata Journal, vol. 6, No. 4, New York, Sage.

Drukker, D. M. (2003), "Testing for serial correlation in linear panel-data models", The Stata Journal, vol. 3, No. 2, New York, Sage.

ECLAC (Economic Commission for Latin America and the Caribbean) (2014), Preliminary Overview of the Economies of Latin America and the Caribbean, 2014 (LC/G.2632-P), Santiago.

(n/d), Maritime and Logistics Profile of Latin America and the Caribbean, [online] http://perfil.cepal.org/l/ en/start.html.

Fay, M. and M. Morrison (2007), Infrastructure in Latin America and the Caribbean: Recent Developments and Key Challenges, Washington, D.C., World Bank.

Gangl, M. (2010), "Causal inference in sociological research", Annual Review of Sociology, vol. 36, Palo Alto, Annual Reviews.

Girón, A. (2015), "Zonas de Libre Comercio. ¿Un camino para el desarrollo?", Problemas del Desarrollo, vol. 46, No. 180, Amsterdam, Elsevier.

Greene, W. (2003), Econometric Analysis, New Jersey, Prentice Hall. (2001), "Estimating econometric models with fixed effects", Leonard N. Stern School of Business Working Paper, No. 44, New York, New York University.

Grossman, G. M. and E. Helpman (1993), Innovation and Growth in the Global Economy, Cambridge, MIT Press.

Grossmann, H. and others (2007), "Growth potential for maritime trade and ports in Europe", Intereconomics, vol. 42, No. 4, Amsterdam, Elsevier.

Guisan, M. C. (2008), "Rates, ratios and per capita variables in international models: analysis of investment and foreign trade in OECD countries", International Journal of Applied Econometrics and Quantitative Studies, vol. 5, No. 2, Santiago de Compostela, University of Santiago de Compostela.

Hausman, J. A. (1978), "Specification tests in econometrics", Econometrica, vol. 46, No. 6, New York, Econometric Society.

López-Bermúdez, B., M. J. Freire and C. Pais (2018), "Crecimiento económico y transporte marítimo en América Latina, 2000-2015: los efectos de políticas comerciales y modelización con datos de panel", Regional and Sectoral Economic Studies, vol. 18, No. 1, Santiago de Compostela, University of Santiago de Compostela.

Marques, A. C. and J. A. Fuinhas (2012), "Are public policies towards renewables successful? Evidence from European countries", Renewable Energy, vol. 44, Amsterdam, Elsevier.

Micco, A. and N. Pérez (2001), "Maritime transport costs and port efficiency", paper presented at the seminar Towards Competitiveness: The Institutional Path, Inter-American Development Bank (IDB), Santiago, 16 March [online] http://citeseerx.ist.psu.edu/viewdoc/download?doi=10.1.1.194.6075\&rep=rep1\&type=pdf.

Núñez-Sánchez, R. and P. Coto-Millán (2012), "The impact of public reforms on the productivity of Spanish ports: a parametric distance function approach", Transport Policy, vol. 24, Amsterdam, Elsevier.

Pesaran, M. H. (2004), "General diagnostic tests for cross section dependence in panels", CESifo Working Paper, No. 1229, Munich, CESifo Group Munich. 
Prais, S. J. and C. B. Winsten (1954), "Trend estimators and serial correlation", Cowles Commission Discussion Paper, No. 383, Chicago, The University of Chicago.

Radelet, S. and J. Sachs (1998), "Shipping costs, manufactured exports, and economic growth", paper presented at the Annual Meeting of the American Economic Association, Chicago, 3-5 January.

Ramos-Real, F. J. and B. Tovar (2010), "Productivity change and economies of scale in container port terminals: a cost function approach", Journal of Transport Economics and Policy, vol. 44, No. 2, University of Bath.

Redding, S. (2002), "Specialization dynamics", Journal of International Economics, vol. 58, No. 2, Amsterdam, Elsevier.

Reed, W. R. and R. Webb (2010), "The PCSE estimator is good--just not as good as you think", Journal of Time Series Econometrics, vol 2, № 1, Berlin, De Gruyter.

Rivera-Batiz, L. A. and P. M. Romer (1991), "International trade with endogenous technological change", European Economic Review, vol. 35, No. 4, Amsterdam, Elsevier.

Robertson, D. and J. Symons (2000), "Factor residuals in SUR regressions: estimating panels allowing for cross sectional correlation", CEP Discussion Papers, No. CEPDP0473, London, London School of Economics and Political Science.

Rodrigue, J. P., C. Comtois and B. Slack (2013), The Geography of Transport Systems, New York, Routledge.

Rodrigue, J. P. and others (2010), "Functions and actors of inland ports: European and North American dynamics", Journal of Transport Geography, vol. 18, No. 4, Amsterdam, Elsevier.

Rodríguez, M. (2017), "El efecto del gasto público sanitario y educativo en la determinación del bienestar de los países de la OCDE", doctorate thesis, La Coruña, Faculty of Economics and Business, University of A Coruña.

Roll, Y. and Y. Hayuth (1993), "Port performance comparison applying data envelopment analysis (DEA)", Maritime Policy and Management, vol. 20, No. 2, Abingdon, Taylor \& Francis.

Romer, P. M. (1990), "Endogenous technological change", Journal of Political Economy, vol. 98, No. 5, Chicago, The University of Chicago Press.

Sánchez, R. (2004), "Puertos y transporte marítimo en América Latina y el Caribe: un análisis de su desempeño reciente", Natural Resources and Infrastructure series, No. 82 (LC/L.2227-P), Santiago, Economic Commission for Latin America and the Caribbean (ECLAC).

Sánchez, R. and others (2015), "Transporte marítimo y puertos: desafíos y oportunidades en busca de un desarrollo sostenible en América Latina y el Caribe", Natural Resources and Infrastructure series, No. 176 (LC/L.4119), Santiago, Economic Commission for Latin America and the Caribbean (ECLAC).

Schurer, S. and J. Yong (2012), "Personality, well-being and the marginal utility of income: what can we learn from random coefficient models?", SEF Working Paper, No. 01/2012, Wellington, Victoria University of Wellington [online] http://researcharchive.vuw.ac.nz/handle/10063/2040.

Schwab, K. (ed.) (2016), The Global Competitiveness Report 2016-2017, Geneva [online] http://www3. weforum.org/docs/GCR2016-2017/05FullReport/TheGlobalCompetitivenessReport2016-2017_FINAL.pdf.

Serebrisky, T. and others (2016), "Exploring the drivers of port efficiency in Latin America and the Caribbean", Transport Policy, vol. 45, Amsterdam, Elsevier.

The Maritime Executive (2014), "Drewry: GDP vs TEUs", Fort Lauderdale, 8 September [online] https://www. maritime-executive.com/article/GDP-vs-TEU-Drewry-2014-09-08.

UNCTAD (United Nations Conference on Trade and Development) (n/da), "Review of Maritime Transport (Series)" [online] https://unctad.org/en/pages/publications/Review-of-Maritime-Transport-(Series).aspx. (n/db), "UNCTADSTAT" [online] http://unctadstat.unctad.org.

Wooldridge, J. M. (2010), Econometric Analysis of Cross Section and Panel Data, Cambridge, MIT Press. (2003), "Cluster-sample methods in applied econometrics", The American Economic Review, vol. 93, No. 2, Nashville, American Economic Association.

World Bank (n/d), "Indicators" [online] https://data.worldbank.org/indicator?tab=all. 